\title{
Human Capital and Its Influence on Sustained Economic Growth in Romania
}

\author{
Cismaș Laura Mariana ${ }^{1}$, Miculescu Andra ${ }^{2}$, Oțil Maria ${ }^{3}$
}

\begin{abstract}
:
The present article draws attention to the conditions necessary so that the effects of education on human capital development and economic development should record maximum values. The paper emphasizes the idea that investments in education become ineffective unless accompanied by a suitable and appropriate strategy for economic and social development, based on socio-economic and political stability, and by the existence of a direct relationship between income, occupation and level of education and professional training.
\end{abstract}

The concepts of social capital and psychological capital, both being considered as influencing development theory, practice and policy although they bring about less clear and direct results.

The paper draws attention to the multidimensional character of the economic development, on the competitiveness, considering that economic development can therefore express all quantitative, qualitative and structural transformations occurring both within economic processes and along scientific research and manufacturing technologies, in the mechanisms regarding the operation of the economy, namely thinking patterns and the behavior of individuals.

On the other hand, the New Economy is described synonymous with the knowledge economy in the broader context of the knowledge society, considering the knowledge based economy, knowledge representing an important factor in determining economic growth.

Keywords: Education, human capital, social capital, investment, economic growth, competitiveness.

JEL Classification: E12, D03, 043, Z13.

\footnotetext{
${ }^{1}$ Professor, West University of Timisoara, Faculty of Economics and Business Administration ${ }^{2}$ Lecturer, West University of Timisoara, Faculty of Economics and Business Administration ${ }^{3}$ Lecturer, West University of Timisoara, Faculty of Economics and Business Administration
} 


\section{Introduction}

Since 1950, starting with the interest shown in various studies on economic growth and from the scarce explanation of the increase based on standard factors of production, an idea emerged, which later led to the genesis of the concept of human capital. Abramovitz (1956) was considered to be the man who, already in 1956, described this inability to build traditional factors (capital, labor, land) in explaining economic growth, naming the unexplained part as "a measure of our ignorance". In the production process, the classical economists identified and defined three factors of production: land, physical capital and work capital (labor force). Land is the sine qua non condition for the existence of crops, farms, agricultural developments, industrial enterprises, farms etc., are set up on it, and also, in general, the sites necessary to conduct the entire economic activity of a society. To achieve all this there would be required another factor, namely labor.

In the classical approach, physical capital was seen, in corpore or separately, as physical and monetary assets used to purchase everything that was necessary to achieve a production, some construction, the proper functioning of the economic activity. These traditional production factors, which entered the production process in different combinations along with goods and services, were used by individuals who pursued their own interests by obtaining a maximum possible performance. Under the influence of Adam Smith, the classics felt that by joining these individual efforts at large-scale, the distribution of economic resources was accomplished to achieve their more productive use. The workers formed a non-distinctive collective mass, and were not considered in terms of their knowledge and skills. However, Adam Smith estimated that it wasn't the collective mass that could be considered useful in the economic activity, but more so the ,talents and skills acquired by the inhabitants or members of society"

Education further guides individuals towards saving, thus turning into an essential element of the social inclusion policy. The skills acquired by individuals allow them meaningful participation to the economic and social development of regional and national economic and social development. Skills' improvement is of paramount importance for the short term economic recovery in Romania and in order to cope with the impact of the crisis on employment it is essential to improve its monitoring, evaluation and forecasting, as well as ensuring compatibility between the skills' supply and demand. The issue of human resource is very topical, especially for the Romanian society characterized by vast social and economic discrepancies." Building a strategy for economic growth and development supposes, identifying a series of measures that will contribute to preserving, enhancing and harnessing of all the resources of a country at a given time (Hategan et al., 2017).

Also, these talents and skills came at a cost that every individual was responsible for, and once acquired, they could constitute a kind of capital, i.e. "a fixed asset and accomplished, so to speak, in his own person". In this regard, a special contribution 
belonged to Denison (1962) who, in his 1962 research entitled "The Sources of Economic Growth in the United States", examines in detail the sources of growth in the U.S. between 1909 and 1959, showing that if a part of the increase is related to the standard reasons (increased supply of capital, economies of scale), perhaps the most important factor would be considered the benefits of investments in education and knowledge. Specifically, he introduces education (as a main investment in human capital) in the equation of a production function, as a reflection of improving the quality of labor.

Denison thus identifies a share of $23 \%$ of economic growth resulting from higher education of the labor force and $2 \%$ as a result of the advance of knowledge. Since the 1960s, work started to be increasingly seen in terms of quality, especially considering the level of education and workforce training. Labor quality, symbolized by human capital, become important for the competitiveness of an economy. The concept of capital includes skills and other attributes of individuals that generate personal, economic and social benefits. Some of these qualities, knowledge, skills, are gained through education and learning and / or acquired experience in the field of work. "Human capital includes certain innate capacities of individuals that can be enriched and valued in the labor market" (Cismaş and Costea, 2012). Also, some aspects of motivation and well-being, as well as attributes like the physical, emotional and mental health of individuals, are regarded as human capital. The OECD report entitled "The Well-being of Nations The Role of Human and Social Capital", defined human capital as "the skills, knowledge, competencies and attributes embodied in individuals that facilitate the creation of personal, social and economic wealth" (OECD, 2010).

Schultz (1961) described the concept of human capital and developed the concept of investment in human capital. Since the beginning of his article, Schultz states: „Although it is clear that the population acquires useful skills and knowledge, it is not obvious that these skills and knowledge are a form of capital, that this particular capital is a substantial part of the product of a deliberate investment, that it grew at a much faster rate than the conventional capital (non-human), and that its growth may well be the most distinctive feature of the economic system". Schultz stated the connection between the quality of human capital (considered as level of education and health of the working population) and economic growth, noting that the working population is not the only factor of growth, given the very different rates of economic growth among countries with somewhat similar levels of schooling (education). Schultz placed human capital on a key level, particularly with reference to the agricultural sector and considering that training and education are essential means to improve productivity and the agricultural income growth.

In his work, "Investment in Human Capital", focusing on the qualitative dimension of the labor factor, Schultz (1961) raises the question of difficulties in measuring human capital, linked to the distinction between "spending for consumption and investment". Even if he gives education the basic role in human capital formation, he 
notes that there are five sources of production and of enhancing human capital, namely:

$\checkmark$ health services (including infrastructure) with direct effects on increasing life expectancy and quality;

$\checkmark$ specific training in the workplace (including learning);

$\checkmark$ formal education at all levels;

$\checkmark$ study programs and adult training outside firms;

$\checkmark$ migration of the workforce and of their families to increase employment opportunities.

For Schultz human capital is a scarce resource that must be developed, education and health being considered as key variables in explaining economic developments in the twentieth century. In recent literature there is interest in deepening the relationship between human capital and economic growth or national competitiveness. The difference from previous studies stems from the involvement of new variables characteristic of the current economy. For example, the issue of the convergence of poor countries towards developed countries was explained by the absolute value of the differences in capital stocks in the two types of countries (Cohen and Soto, 2001). This relationship was highlighted by the analysis of OECD countries through the positive link between human capital and GDP per capita.

Hanushek (2016) is conducting multiple studies to determine to what extent and at what level education contributes to national economic growth. Although it has many positive and strong links between education levels and national productivity, or the size of national income, Hanushek concludes that "just by adding more years of schooling without increasing historical cognitive abilities, a small measure ". Also, the explanations of Luthans and Youssef (2004) incorporate the crucial temporal factor for human capital and its role in the economy. In their view, "human capital is an investment in the competitive advantage" of the nations. As the set of abilities and knowledge is renewable, human capital becomes a substitute source "when traditional resources are no longer qualified as ideal for competitive advantage".

La Fuente and Cicoone (2003) analyze the role of human capital in the knowledge economy. Their research reconfirms that at the microeconomic level, education is the main determinant of individual incomes, responsible for the standard of living of citizens. They analyzed the role of human capital in the knowledge economy. Their research reconfirms the fact that at the microeconomic level, the level of education is the main determinant of individual incomes, responsible for the citizens' standard of living. At macro level, the authors agree that an additional year of education can contribute to growth productivity with 5\% short and long term. Long-term growth is explained by the contribution of human capital to technological development and the adoption of new technologies. The authors acknowledge the uncertainty about the exact size of human capital's contribution to economic growth due to variables used in the literature. 


\section{The role of social and psychological capital}

The economic situation of countries, respectively their development potential, has always been the central object of interest to researchers. Much of the research starts from the analysis of physical capital per person, considered to reflect the economic situation. Current research performed comparatively on both the developed countries and the least developed ones have indicated that the differences can be attributed to the institutional matrix that was found to differ from one country to another. In this view, the researchers changed their analysis on the topic of development, seeking explanations in the interdisciplinary scope, considering thus approaches of sociology and psychology respectively, thus emerging two other forms of capital - the social capital and the psychological capital.

Early attempts to define social capital focused on the degree to which "social capital as a resource should be used for public good or for the benefit of individuals; it can be defined as representing the norms and social relations embedded in the societies' social structure, due to which people coordinate their actions in order to achieve the expected results" (Cismaş and Sîrghi, 2013). It can be noted that social capital comprises those features of social relationships, interpersonal trust, norms of reciprocity, participation in civic organizations and interpersonal and interorganizational networks which facilitate cooperation and collective action oriented towards a general benefit, being thus incorporated into the structure and quality of social relationships between people.

"Social capital can thus be defined as a set of norms and values shared by the members of a group leading to cooperation between them, although it is questionable whether the sharing of these norms and values indeed lead automatically to the creation of social capital, as such values are not necessarily positive or desirable" (Cismaş et al., 2015). Rules and associations are thus an attribute of a relatively stable social structure, resulting in social interaction and the way individuals interact with one another. For certain rules to represent social capital, they must lead towards cooperation, reflecting the traditional virtues (honesty, respect commitments, reciprocity).

Social capital, in terms of social potential, is considered to improve the economic activity background in a way similar to technical infrastructure; social capital influences the quality of education and health, facilitates access of individuals to markets, supports complex operations and enables the activities' long-term planning. Other ideas state that generalized trust (based on the ethical behavior and habits and moral norms of reciprocity tacitly accepted by the members of the community) is essential for cooperation and economic development (Putnam, 1993), determining the industrial structure of an economy (Fukuyama, 1995; 2001), it can be argued that social capital is a necessary precondition for successful development, but a strong rule of law and basic political institutions are necessary to build social capital. Fukuyama considers that a strong social capital is necessary for a strong democracy 
and strong economic growth. The USA, Japan, and Germany are societies reflecting a high level of trust, where trust is not restricted to the family settings, but rather generalized, and there can be easily found large, professionally managed corporations, as people are better able to cooperate on an enlarged scale, while in Italy and France, for example, smaller and family owned firms dominate the industrial structure (Criveanu and Iordache, 2015; Nulla and Koumparoulis, 2013).

Fukuyama argues that the strength of family ties could be detrimental to the emergence of large organizations and, if they are not accompanied by a strong culture of work and education, it can lead to stagnation. Even so, this does not necessarily mean that a high degree of confidence, and therefore, larger organizations are better for a global economic growth, since what they gain in size can be lost in the flexibility and promptness of the decision-making process. But it was noted that the companies which reflected a high level of confidence proved to function even under few rules or mechanisms for implementing the contract. This leads to the consideration of trust as a component of a value system that stabilizes interactions in a society, reduces uncertainty and facilitates the grounding of order.

Paldam and Svendsen (2000) define social capital as "the density of trust within a group", calling into question the link between theories of social capital and good will (management), credibility (macroeconomic policies), cooperative solutions (game theory) and the rules of group (anthropology and psychology). The economic function or the more "productive" one of social capital is to enable individuals to achieve goals more difficult to reach otherwise, or to diminish the costs of achieving them; in other words, to reduce transaction costs (Coleman, 1990) associated with coordinating mechanisms (hierarchy, contracts), resulting in significant transaction costs and promoting cooperation. The less developed countries cannot ignore the issue of social capital; former communist countries are facing a shortage of social capital, the communist era being characterized by hypertrophic relationships between the state and the citizen, namely the lack of voluntary association in joint projects.

On the other hand, the confidence level has proven to be much lower, given that individuals were not competing for limited resources - the latter having immediate effect on trade. Also, it can be seen that the lack of informal rules to constrain individual behavior often proved the legislative efforts of states as useless.

One of the most relevant contributions of social capital is brought to the human capital formation, which was recognized early by Coleman (1990), who argued that the same basic individual skills have much better chances of being well cultivated and developed in an environment which is socially rich, stressing the link between social capital and education. He also stresses that the social capital, causing a certain degree of social cohesion can have a relevant influence on crime rates and violence (Coleman, 1990). A positive correlation between the average education level and social capital was also indicated by Helliwell and Putnam (1999), highlighting the 
virtuous dynamics between human capital and social capital accumulation, the policies aiming to improve the confidence level being considered to be the base of a multiplier mechanism. These policies can be relevant for growth and long-term development, i.e., the level reached based on reputation can substitute the confidence level in well-running markets, but in the case of emerging markets such stability is absent, so that the level of trust may determine whether some innovative activities will develop or not.

Another difference in achieving a competitive advantage in the global market in the immediate future may represent the investment in and the development of psychological capital. Until recently, little attention was paid by psychology to healthy individuals in terms of growth, development and overcoming their potential, being particularly interested in clinical cases or issues of dysfunctional behavior. In this case there is again the need for a change of approach, focusing on the potential to build a sustainable competitive advantage based on a positive approach; thus arises Gallup's management approach based on strengths, according to which individuals are selected, developed and are driven on the basis of their strengths to the expense of their weaknesses (Buckingham and Clifton, 2001; Buckingham and Coffman, 1999).

"Compared with genetic determinants, positive psychological traits reflect a degree of malleability, so we can say that human potential is proving to be more resilient than previously assumed; this leads to the consideration according to which the development of the level of knowledge, skills and technical skills is no longer enough. Positive psychological traits (self-confidence, optimism, perseverance, hope, to maintain a balance, social skills, gratitude, forgiveness and emotional intelligence) can record growth and development in the conditions of optimum situational factors or exciting moments" (Manta et al., 2017). In the short term, however, there may be significant changes, especially since the current environment is very dynamic and constantly changing, with an emphasis on continuous personal development, so the long-term initiatives on the development of talent, of positive virtues and of the strength of character and other largely stable personality traits are not effective in terms of cost and in many cases are also quite impossible. Thus, such initiatives can be rather transferred to the responsibility of educational institutions.

On the other hand, quantifying profit from investment in human resources is considered to be of vital importance for decision makers (Cascio, 1991; Huselid, 1995; Kravetz, 1988), various investment competing for limited resources, such as an adequate profit becomes the critical factor in determining the extent to which human resource development initiatives will receive organizational support. However, questionable assumptions and difficulties associated with quantifying these profits may divert available resources towards the accumulation of more traditional goods such as physical, financial or technological capital, thus failing those skills or abilities that can influence positive performance - such as self- 
efficiency hope, optimism and resilience / spiritual mobility (Luthans, 2002; Luthans and Avolio, 2003; Luthans et al., 2004).

\section{The relationship education - human capital development}

In Romania, as a member state of the European Union should increase the quality of jobs, the working environment and aim to increase competitiveness in the labor market and increase the participation rate especially for those with low incomes in accordance with the guidelines of the economic policies employment established by the 2020 strategy. Romania is ranked World Competitiveness Yearbook in 2003, currently in position 51. Romania's evolution in the WCY rankings is relatively small, with the average position for the period 2003-2016 being between 50 and 51 .

Figure 1. Romania evolution on the WCY

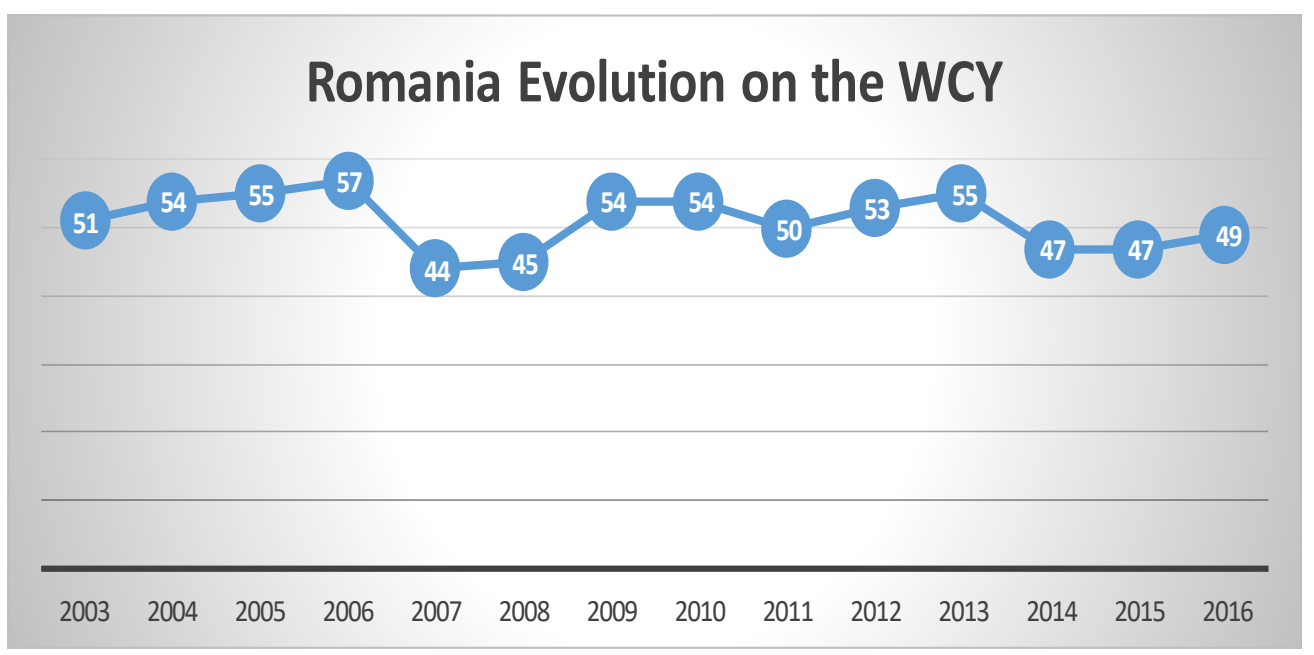

Source: Authorized by information provided by World Competitiveness Yearbook $2003-$ 2016:

Analyzing the trend for the period 2003-2016, the following aspects are observed:

- In the period 2003-2006, Romania recorded the most unfavorable competitive positions over its subsequent evolution;

- the years 2007-2008 correspond to the best performing positions registered by Romania so far, and this can be explained by the positive effects of integration into the European Union;

- the positions occupied in WCY 2014 and WCY 2015 indicate a post-crisis macroeconomic recovery, together with greater national stability;

- The latest WCY 2016 report places Romania on 49th place, a negative evolution with two positions, compared to the previous one. 
The main target of the European Union according to which Member States set their own national targets, is that in 2020 the employment rate by sex with vâerste between 20-64 years to reach the target of 75\%. During 2000-2016, the evolution of the employment rate in Romania, by sex and age group 20-64 years is shown in Table 1.

Table 1. Employment rate by sex and age group 20-64 in the period 2000-2016 (\%)

\begin{tabular}{|l|l|l|l|l|}
\hline \multicolumn{5}{|c|}{ Employment rate by sex and age group 20-64 in the period 2000-2016 (\%) } \\
\hline Year & Total & Male & Female & $\begin{array}{l}\text { The Difference } \\
\text { percent }\end{array}$ \\
\hline 2000 & 69,1 & 75,4 & 63,0 & $\mathbf{1 2 , 4}$ \\
\hline 2001 & 68,3 & 74,6 & 62,3 & $\mathbf{1 2 , 3}$ \\
\hline 2002 & 63,3 & 70,1 & 56,8 & $\mathbf{1 3 , 3}$ \\
\hline 2003 & 63,7 & 70,5 & 57,0 & $\mathbf{1 3 , 5}$ \\
\hline 2004 & 63,5 & 69,7 & 57,4 & $\mathbf{1 2 , 3}$ \\
\hline 2005 & 63,6 & 70,4 & 56,9 & $\mathbf{1 3 , 5}$ \\
\hline 2006 & 64,8 & 71,2 & 58,5 & $\mathbf{1 2 , 7}$ \\
\hline 2007 & 64,4 & 71,0 & 57,9 & $\mathbf{1 3 , 1}$ \\
\hline 2008 & 64,4 & 71,6 & 57,3 & $\mathbf{1 4 , 3}$ \\
\hline 2010 & 63,5 & 70,7 & 56,3 & $\mathbf{1 4 , 4}$ \\
\hline 2011 & 63,3 & 70,8 & 55,9 & $\mathbf{1 4 , 9}$ \\
\hline 2015 & 62,8 & 69,9 & 55,7 & $\mathbf{1 4 , 2}$ \\
\hline 2016 & 62,2 & 68,9 & 54,8 & $\mathbf{1 4 , 1}$ \\
\hline
\end{tabular}

Source: Own calculations made based on data from Eurostat source.

In the entire analyzed period there was a significant increase in the gender (except 2006) and in the year 2016 the employment rate gap versus Europe 2020 target is 12.2 percentage points. The data presented in Table 1 we can say that the employment rate oscillates around $63-64 \%$, with an average of about $71 \%$ for men and 56-57\% for women (Thalassinos et al., 2011; Stamatakis, 2016).

Over the period 2000-2016 Romania recorded a rate of employment in the 20-64 age group only in the years 2000 and 2001, in the remaining years this rate is significantly lower than European ones. In this way, as a member state of the European Union, Romania should increase turnout by policies that encourage gender equality and equal pay, "active aging" population, increasing job quality, youth employment. Educational factor, as we said above has a major impact on the labor market, so it should be ensured qualification recognition systems and skills acquired and promote them. The objectives of the employment rate is calculated by reporting the share of employed in the 20-64 age group in the total population in the age group 20-64 years (Sultanova and Chechina, 2016; Guskova et al., 2016).

According to the latest PISA test results (2009), the situation in the European Union is worsening, about $20 \%$ of young people being barely able to read (have real difficulty in reading), compared with $18 \%$ in the US, 14\% in Japan, $10 \%$ in Canada and $6 \%$ in South Korea (OECD, 2010). According to the PISA study, in 2009, on 
average $19.6 \%$ of the assessed students showed low performance in reading and writing, or respectively low or basic knowledge in the field. Among the European Union countries there were recorded very large differences in reading performance; thus, in Finland only $8.1 \%$ of students have low levels of reading performance, in other four countries (Estonia, the Netherlands, Poland, Czech Republic) up to 15\% of pupils fall into this category. The percentage of pupils aged 15 who only recorded level 1 (of five) in reading was based on the same 2012 PISA study data, as shown in Figure 2. In most states, this percentage varies around the European average, but two countries, Bulgaria and Romania, are characterized by a high number of pupils with poor reading and writing performance, i.e., over $40 \%$.

Figure 2. Pupils with low reading, 2012, \% out of total. Percentage of people with low levels regarding reading skills (the PISA study).

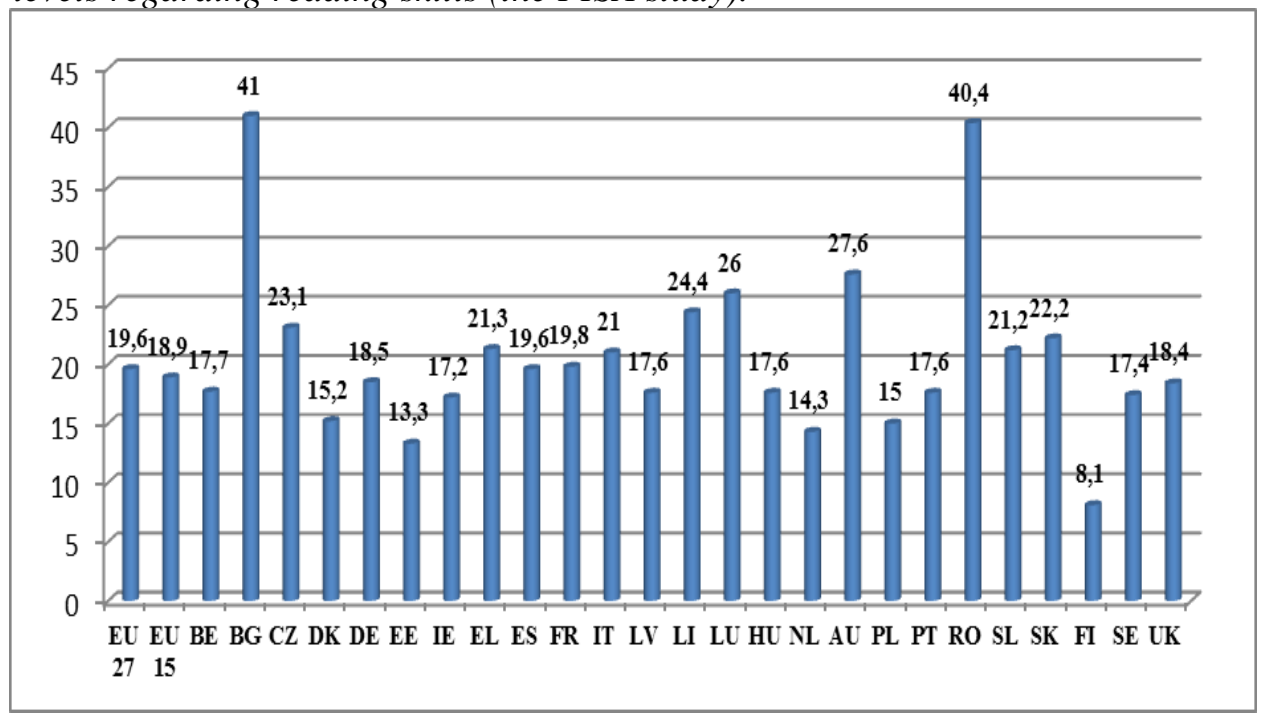

Source: Eurostat.

Within the EU, there are large discrepancies in the number of people able to complete only the least complex tasks of reading (such as locating information, identifying the main theme of a text). Within the EU countries there are currently few recent studies on literacy rates. Analysis conducted in Germany, France, Britain indicated that one adult in five only holds low or basic knowledge, which translates into more than 75 million people in the EU for whom there is a real risk of being excluded from any form of education and will not be able to join the labor market or to cope with daily issues of life. The objective put forward by the European Commission for 2020, in that regard, indicates limiting the number of children of the age of 15 who have only basic knowledge (or no) to stay below 15\%, taking into account the need to update the skills of reading and writing, especially considering the case of a population which is evidently aging. 
The need to correct this problem is highly emphasized at European level. The expert group report on the crisis at European level regarding reading and writing skills emphasizes that good reading and writing skills are essential for improving the lives of citizens and the promotion of knowledge, innovation and economic growth, showing that just as smart growth means knowledge and innovation, investment in reading literacy is a prerequisite to achieve such growth.

Another indicator widely used in econometric models of growth relates to public and private expenditure on education as percentage of the GDP, for all levels of education. In all European Union countries, public expenditure in the GDP allocated to education represents the vast majority of total funding. The EU average in 2015, according to Eurostat data, was of $5.41 \%$ of the GDP, the situation across countries ranging from $4.24 \%$ for Romania and $8.72 \%$ of the GDP for education in Denmark. Following the evolution of this indicator for the countries and the years for which data are available, we can state that the situation has evolved little in the past decade. Private financing in European countries was in 2009, on average, $0.79 \%$ of the GDP, the lowest proportion of private investment being registered in Romania $(0.11 \%)$.

The annual expenditure on education per pupil / student relative to GDP / capita (for all levels of education) is more balanced among these countries, the European average being $27.4 \%$ in 2013, in Romania this percentage being only $21.6 \%$. Regarding the average participation rate of students aged 15-24 years to the education system (ISCED 1-6), it was slightly over $61 \%$ in the European Union, but differences between countries are extremely high. If $70 \%$ of young people aged 1564 are enrolled in some form of education in countries such as Finland (71\%), Poland (70.8\%), Slovenia (71\%), Belgium (69 2\%), the Netherlands (69\%), this percentage is below the European average in Cyprus, Malta, Bulgaria, Romania, Slovakia or Austria or the UK.

The Education and Training 2020 strategic framework adopted by the European Commission proposed at the end of the current decade five objectives that concern all age groups of the population, namely: i) participation in preschool education of children aged 4 and up to school age to be greater than 95\%; ii) $15 \%$ should represent the maximum percentage of 15 year olds with poor reading performance; iii) the average dropout rate should not exceed $15 \%$ (objective indicated also in the Europe 2020 strategy); iv) at least $40 \%$ of adults aged 30-34 years should be graduates of higher education (also provided in the European strategy for 2020); v) the share of people aged 25-64 who should participate in lifelong learning programs to represent about $15 \%$.

Analysis of Romania's Competitiveness Pillars in the GCR 2015-2017 Romania is included in the The Global Competitiveness Report starting with 2001/2002, where it occupied position 61. Analyzing the evolution of Romania's competitiveness in the Global Competitiveness Report, there is an oscillating trend, and 12 or 10 positions (2004/2005 compared to 2005/2006, respectively 2011-2012 versus 2012-2013) 
influenced by at least four directions: a). the macroeconomic changes corresponding to the pre-accession period in the EU (2004-2007), when greater stability was recorded; b). the favorable effects on the Romanian competitive potential after the integration into the Single European Market (after 2007); c). the consequences of the economic crisis (2010-2014) that have weakened the positive trend from the previous period; d). post-crisis economic recovery.

Figure 3. Evolution of Romania's competitive position in The Global Competitiveness Report 2001/2002, 2016/2017.

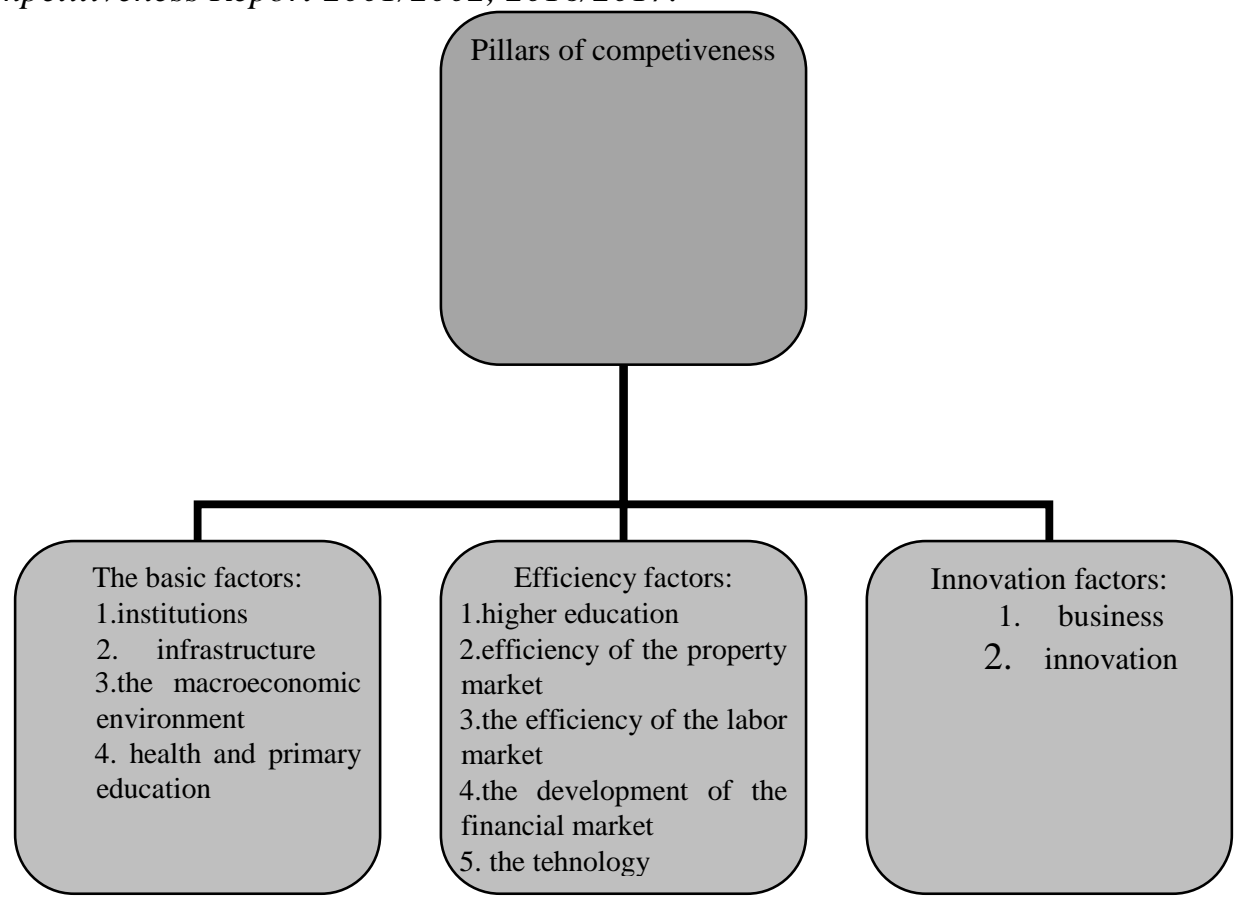

Source: The Global Competitiveness Report 2001/2002, 2016/2017.

In GCR 2009/2010 and 2015/2016, Romania ranks among the intermediate stage countries to the third stage of development. This was only a stage success, Romania being still poorly competitive at the core factors and competitiveness efficiency. In relation to the EU Member States, Romania has significant gaps in almost all pillars of competitiveness, especially in the general national infrastructure. Compared with the previous ranking, GCR 2015/2016, Romania lost 9 positions, the lowest listed and having a negative trend, being pillars 11 and 12 , that is the innovation factors. Figure 4 illustrates the upward trend of Romania for 2010-2016, for both indicators, GDP and GDP per capita. In both situations the growth rate was lower in the 20102013 period, as expected under the impact of the economic crisis, and more dynamic in the period 2013-2016. Starting with 2014, GDP growth has increased, as evidenced by an increasing slope. 
Figure 4. The upward trend of Romania for 2010-2016, for both indicators, GDP and GDP per capita

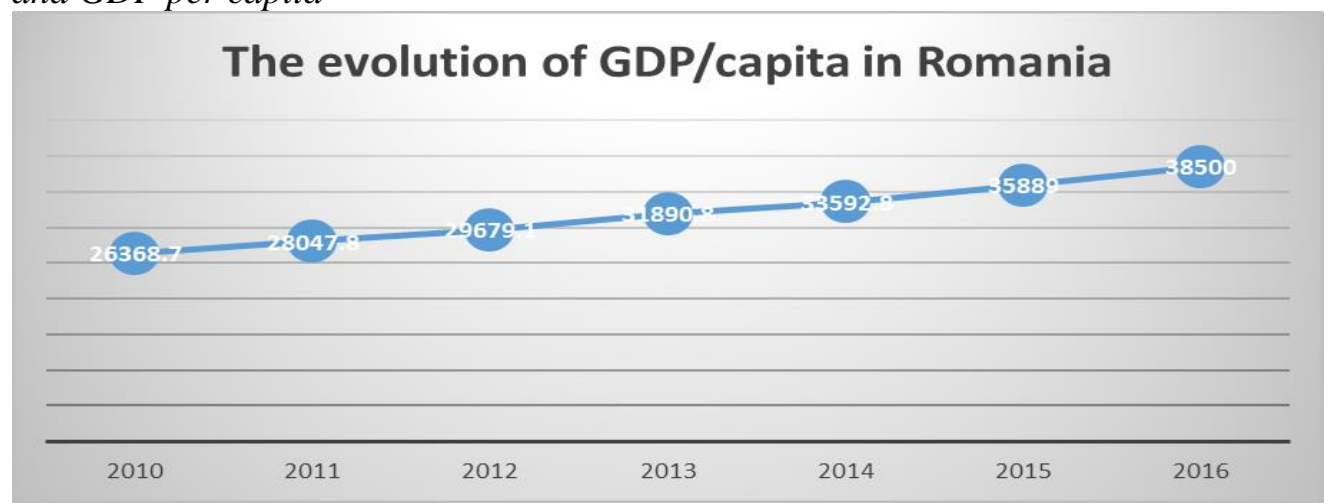

Source: The Global Competitiveness Report 2001/2002, 2016/2017.

Despite these developments, Romania ranks 27th in the EU28, ahead of Bulgaria, according to GDP per capita. The share of GDP per capita in Romania compared to the EU27 average has evolved from $24.7 \%$ in 2010 to $29.65 \%$ in 2016 and the forecasts show that in about 6-7 years it could reach $65 \%$ of the European average (NBR, 2016). Although Romania has been remarkable in previous years, with rising rhythm, the risk of poverty and social marginalization has remained high, $37.4 \%$ in 2015, down from $41.5 \%$ in 2010. High rates of Romania's economic growth is largely explained by government measures on tax cuts, "increasing consumption and recovering investment" (European Commission, Country Report, Romania, 2016).

Figure 5. The Evolution of Romania's competitive position in The Global Competitiveness Report 2001-2017

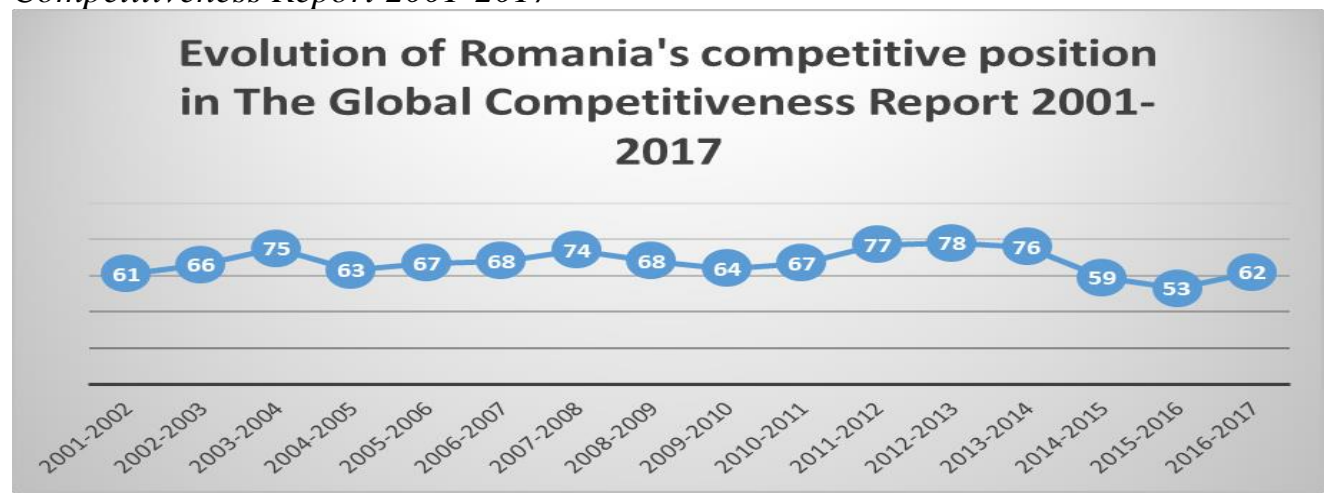

Source: Data provided by the GCR rankings.

The reduction in value added tax from $24 \%$ to $20 \%$ reduced the rate of income tax and exempted certain dividends from corporation tax. The new government's latest measures are that future increases will also be driven by low borrowing costs and business-friendly fiscal policy, which will also increase confidence among foreign investors. In this context, the employment rate has increased steadily since 2011 , 
from $63.80 \%$ to $66 \%$ in 2015, placing Romania in 24th position in the EU28, ahead of Greece (54.9\%), Italy $(60.5 \%)$, Croatia (60.5\%) and Spain $(62 \%)$, and a difference of 4.1 points from the EU average $(70.1 \%)$. The share of total public spending was $34.6 \%$ of GDP on average for the period $2010-2016$, ie $31.49 \%$ in 2016. According to Eurostat data, the highest share of public expenditure, for the 2010-2015 period, corresponds to social protection, with an average of $19.2 \%$, followed by health $(7.2 \%)$, governmental public services $(6.7 \%)$ and education $(5.1 \%)$

\section{The methodology used: The non-linear multi-factor model of economic growth}

The second part of the research presents the links between health status and education, as main components of human capital and economic growth, the methodological approach consisting of a research conceptual multi-factorial nonlinear model that encompasses both theoretical and empirical elements, estimation models, important independent variables and their measurement, and the used methods of analysis. In the theoretical part we highlighted the models and theories of endogenous and exogenous economic growth, and based on this we conducted our empirical approach accomplishing a statistical analysis of the variables used in the models and of significant and defining indicators of the levels and quality of health and education, in correlation with the GDP per capita.

Figure 6. Model of research regarding human capital based on both components

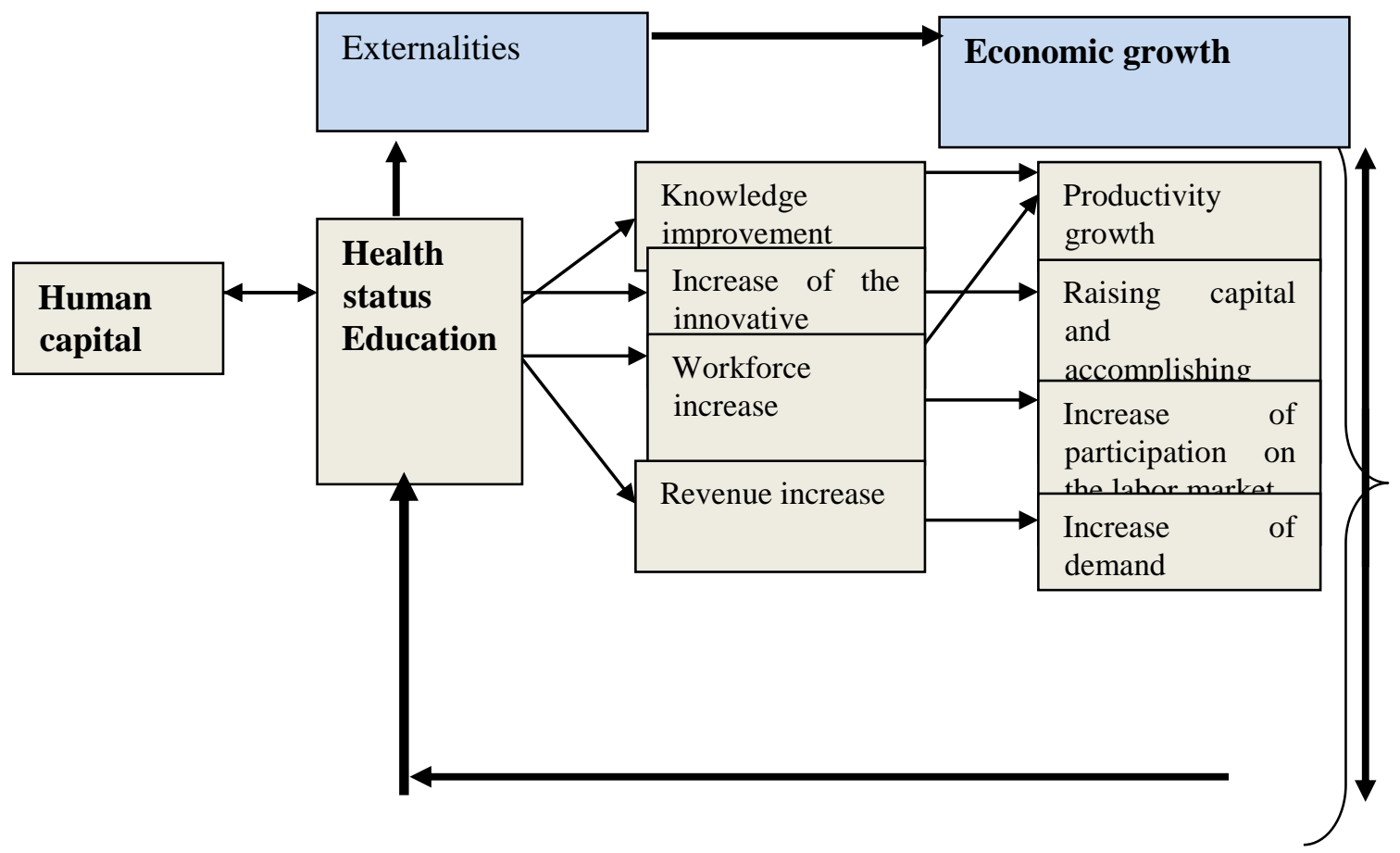


Source: Mehmet Ugur (2012) „Evidence on the relationship between education, skills and economic growth in low-income countries: A systematic review", London: EPPI-Centre, Social Science Research Unit, Institute of Education, University of London.

The correlations between the dependent variable GDP per capita in million euro and the independent variables GFFC - gross formation of fixed capital, foreign direct investment FDI, labor productivity WL - calculated on the total employed population, NU - the number of unemployed, minimum wage in euro, E- emigrants expressed by the number of persons in the age group (15-49 years), and health related expenditure in Romania.

Table 2. Logarithmic values of the dependent variable and independent variables

\begin{tabular}{|c|c|c|c|c|c|c|c|c|}
\hline Year & $\begin{array}{l}\text { PIB } \\
\text { (million } \\
\text { euro) }\end{array}$ & GFFC & $\begin{array}{l}\text { ISD (mil } \\
\text { euro) }\end{array}$ & WL & NU & $\begin{array}{l}\text { Minimum } \\
\text { wage } \\
\text { (Euro/mo } \\
\text { nth) }\end{array}$ & $\begin{array}{l}\text { Emigra } \\
\text { nts } \\
\text { (accordi } \\
\text { ng to } \\
\text { age } \\
\text { category } \\
15-49 \\
\text { years) }\end{array}$ & $\begin{array}{l}\text { Health } \\
\text { related } \\
\text { expenditure } \\
\text { s }\end{array}$ \\
\hline 2004 & $\begin{array}{l}11.98865 \\
89\end{array}$ & $\begin{array}{l}9.528954 \\
09\end{array}$ & $\begin{array}{l}9.585689 \\
856\end{array}$ & $\begin{array}{l}17.18859 \\
032\end{array}$ & $\begin{array}{l}13.23192 \\
067\end{array}$ & $\begin{array}{l}4.2199487 \\
84\end{array}$ & $\begin{array}{l}9.47899 \\
252\end{array}$ & 8.112353887 \\
\hline 2005 & $\begin{array}{l}12.04835 \\
101\end{array}$ & $\begin{array}{l}9.877774 \\
795\end{array}$ & $\begin{array}{l}9.618468 \\
598\end{array}$ & $\begin{array}{l}17.22186 \\
794\end{array}$ & $\begin{array}{l}13.16727 \\
364\end{array}$ & $\begin{array}{l}4.3656431 \\
55\end{array}$ & $\begin{array}{l}9.29999 \\
824\end{array}$ & 8.386514868 \\
\hline 2006 & $\begin{array}{l}12.19095 \\
495\end{array}$ & $\begin{array}{l}10.16486 \\
287\end{array}$ & $\begin{array}{l}9.993556 \\
75\end{array}$ & $\begin{array}{l}17.59745 \\
472\end{array}$ & $\begin{array}{l}13.04005 \\
728\end{array}$ & $\begin{array}{l}4.4961362 \\
65\end{array}$ & $\begin{array}{l}9.56078 \\
595\end{array}$ & 8.513151033 \\
\hline 2007 & $\begin{array}{l}12.32114 \\
49\end{array}$ & $\begin{array}{l}10.71773 \\
67\end{array}$ & $\begin{array}{l}10.44906 \\
237\end{array}$ & $\begin{array}{l}18.05345 \\
872\end{array}$ & $\begin{array}{l}12.81539 \\
79\end{array}$ & $\begin{array}{l}4.7472772 \\
03\end{array}$ & $\begin{array}{l}9.57324 \\
587 \\
\end{array}$ & 8.784877127 \\
\hline 2008 & $\begin{array}{l}12.45506 \\
015\end{array}$ & $\begin{array}{l}10.90937 \\
033\end{array}$ & $\begin{array}{l}10.66359 \\
22\end{array}$ & $\begin{array}{l}18.26848 \\
668\end{array}$ & $\begin{array}{l}12.90778 \\
554\end{array}$ & $\begin{array}{l}4.9315199 \\
34\end{array}$ & $\begin{array}{l}9.86412 \\
283\end{array}$ & 8.935469221 \\
\hline 2009 & $\begin{array}{l}12.39820 \\
096\end{array}$ & $\begin{array}{l}10.35129 \\
35\end{array}$ & $\begin{array}{l}10.79544 \\
461 \\
\end{array}$ & $\begin{array}{l}18.40083 \\
697 \\
\end{array}$ & $\begin{array}{l}13.47215 \\
086\end{array}$ & $\begin{array}{l}5.0050195 \\
55\end{array}$ & $\begin{array}{l}9.96913 \\
483 \\
\end{array}$ & 8.809010203 \\
\hline 2010 & $\begin{array}{l}12.45313 \\
075\end{array}$ & $\begin{array}{l}10.40087 \\
529\end{array}$ & $\begin{array}{l}10.81945 \\
823\end{array}$ & $\begin{array}{l}18.42534 \\
823\end{array}$ & $\begin{array}{l}13.34863 \\
802\end{array}$ & $\begin{array}{l}4.9532180 \\
23\end{array}$ & $\begin{array}{l}10.0141 \\
788\end{array}$ & 8.908276712 \\
\hline 2011 & $\begin{array}{l}12.49848 \\
7\end{array}$ & $\begin{array}{l}10.49381 \\
543\end{array}$ & $\begin{array}{l}10.87018 \\
619\end{array}$ & $\begin{array}{l}18.47657 \\
358\end{array}$ & $\begin{array}{l}13.04118 \\
152\end{array}$ & $\begin{array}{l}5.0575188 \\
8\end{array}$ & $\begin{array}{l}10.0382 \\
37\end{array}$ & 8.904729196 \\
\hline 2012 & $\begin{array}{l}12.54576 \\
22\end{array}$ & $\begin{array}{l}10.51352 \\
483\end{array}$ & $\begin{array}{l}10.91761 \\
255\end{array}$ & $\begin{array}{l}18.52449 \\
708\end{array}$ & $\begin{array}{l}13.10983 \\
523\end{array}$ & $\begin{array}{l}5.0870406 \\
25\end{array}$ & $\begin{array}{l}10.0610 \\
04\end{array}$ & 8.897572943 \\
\hline 2013 & $\begin{array}{l}12.57504 \\
353\end{array}$ & $\begin{array}{l}10.44283 \\
358\end{array}$ & $\begin{array}{l}10.98742 \\
604\end{array}$ & $\begin{array}{l}18.59480 \\
746\end{array}$ & $\begin{array}{l}13.11768 \\
646\end{array}$ & $\begin{array}{l}5.0594254 \\
58\end{array}$ & $\begin{array}{l}10.1087 \\
115\end{array}$ & 8.965125021 \\
\hline 2014 & $\begin{array}{l}12.58370 \\
088\end{array}$ & $\begin{array}{l}10.40369 \\
905\end{array}$ & $\begin{array}{l}11.00139 \\
96\end{array}$ & $\begin{array}{l}18.60927 \\
767 \\
\end{array}$ & $\begin{array}{l}13.12271 \\
132\end{array}$ & $\begin{array}{l}5.2476028 \\
52\end{array}$ & $\begin{array}{l}10.1100 \\
545 \\
\end{array}$ & \\
\hline
\end{tabular}

Source: Logarithmic values accomplished based on Eurostat data.

Starting from Mincer's salary equation, the relations between the level of education and salary, the growth model of Manwik, Romer and Weil showing the importance of adding human capital to Solow's growth model, and from the Cobb -Douglas function of production $(\mathrm{Y}=\mathrm{F}(\mathrm{K}, \mathrm{L}, \mathrm{T})$ have established a non-linear multi-factorial model in which there were considered both the significant indicators of education (minimum wage, FDI, NU, GFFC, E) and those that better quantify the health status of the population (WL, Health related expenditures).mThe non-linear multi-factorial model, where the dependent variable is GDP / capita is as follows: 
$\ln (\mathrm{GDP})=\ln \mathrm{a}+$

$\mathrm{a}_{1} \ln (\mathrm{GFFC})+\mathrm{a}_{2} \ln (\mathrm{FDI})+\mathrm{a}_{3} \ln (\mathrm{WL})+\mathrm{a}_{4} \ln (\mathrm{NU})+\mathrm{a}_{5} \ln (\mathrm{MW})+\mathrm{a}_{6} \ln (\mathrm{E})+\mathrm{a}_{7} \ln (\mathrm{HE})$

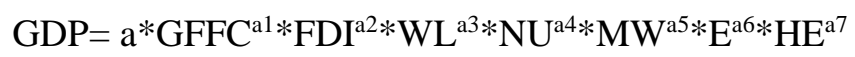

Table 2. The results of the correlations between the independent variables and the dependent variable.

\begin{tabular}{|c|c|c|c|c|}
\hline $\begin{array}{l}\text { Regression } \\
\text { analysis }\end{array}$ & & & & \\
\hline $\begin{array}{l}\text { Correlation } \\
\text { report }\end{array}$ & $99,9 \%$ & & & \\
\hline $\begin{array}{l}\text { Coefficient } \\
\text { of } \\
\text { determination }\end{array}$ & $99,9 \%$ & & & \\
\hline $\begin{array}{l}\text { Standard } \\
\text { error } \\
\text { function }\end{array}$ & 0.001184319 & & & \\
\hline \multirow{2}{*}{$\begin{array}{l}\text { Number of } \\
\text { observations }\end{array}$} & 11,00 & & & \\
\hline & $\begin{array}{l}\begin{array}{l}\text { Degree } \\
\text { freedom }\end{array} \\
\text { frof }\end{array}$ & Sum of squares & Variances & $\mathrm{F}$ \\
\hline Regression & 7 & 0.433360239 & 0.061908606 & 44138.12278 \\
\hline Residual & 3 & 4.20783E-06 & $1.40261 \mathrm{E}-06$ & \\
\hline \multirow[t]{2}{*}{ Total } & 10 & 0.433364447 & & \\
\hline & Coefficients & $\begin{array}{l}\text { Standard error } \\
\text { of coefficients }\end{array}$ & t-Student & Probability \\
\hline Constant & $\begin{array}{l}- \\
574.5812289 \\
\end{array}$ & 15.10354042 & -38.04281731 & 3.99552E-05 \\
\hline FBCF & 0.256257292 & 0.008927493 & 28.70428224 & 9.28403E-05 \\
\hline ISD & $\begin{array}{l}- \\
76.59361622 \\
\end{array}$ & 1.986215961 & -38.56258218 & $3.83638 \mathrm{E}-05$ \\
\hline WL & 76.57278121 & 1.983690173 & 38.6011799 & $3.82491 \mathrm{E}-05$ \\
\hline $\begin{array}{l}\text { Number of } \\
\text { unemployed }\end{array}$ & 0.046857472 & 0.006122546 & 7.65326593 & 0.004632991 \\
\hline $\begin{array}{l}\text { Minimum } \\
\text { wage } \\
\text { (Euro/month) }\end{array}$ & $\begin{array}{l}- \\
0.081506105\end{array}$ & 0.009003736 & -9.052475774 & 0.002847157 \\
\hline Emigrants & 0.234248115 & 0.007233106 & 32.38555015 & $6.47036 \mathrm{E}-05$ \\
\hline $\begin{array}{l}\text { Health } \\
\text { related } \\
\text { expenditures }\end{array}$ & - & 0.013201738 & -3.206329295 & 0.049093697 \\
\hline
\end{tabular}

Source: Data accomplished based on Data Excel.

The non-linear multifactor model that reflects the relationship between the dependent variable GDP / capita and the independent variables GFFC - gross 
formation of fixed capital, foreign direct investment FDI, labor productivity WL calculated on the total employed population, NU- number of unemployed, MW minimum wage in euro, E- emigrants expressed by the number of persons in the age group (15-49 years), HE - health expenditures in Romania.

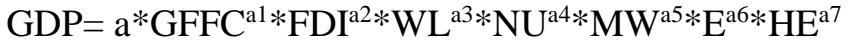

$$
\begin{aligned}
& \mathrm{GDP}=-574.5812 * \mathrm{GFFC}^{0.2562} * \mathrm{FDI}^{-76.5936} * \mathrm{WL}^{76.5727} * \mathrm{NU}^{0.04685} * \mathrm{MW}^{0.0815} * \mathrm{E}^{0.2342} * \mathrm{HE}^{0.0423}
\end{aligned}
$$

The multiple correlation report for the proposed model has a value of $99,9 \%$ indicating a high intensity of the link between the resultant variable and the cumulative action of factorial variables. The same high degree of intensity of the link between GDP / capita and influencers identified is revealed also by the coefficient of determination which is $99.9 \%$, value which shows that $99.9 \%$ of the GDP variation in due to the influence cumulative gross fixed capital formation GFFC, foreign direct investment - FDI, labor productivity WL - calculated on the total employed population, the number of unemployed NU, MW - the minimum wage in euro, $\mathrm{E}$ - as the number of immigrants including people in the age category (15-49 years), HE - health expenditures in Romania.

The consistency of the powers' estimators $a_{i}$ with $i=1,7$ is initially checked via a Student test performed with a significance threshold of 0.95 . The Student test statistical values for each estimator are presented in Table 12 . We can easily notice that for each estimator the statistical values exceed the critical value of the Student test, which is 3.1824 (for a unilateral test with three degrees of freedom). Thus the test's null hypothesis is rejected for all the eight estimators, indicating that they are correct estimators with fundamental values which are different from 0 . Further along in the analysis on the accuracy of the proposed regression model a Fisher test was conducted to verify the model ability to approximate the values of the $\mathrm{Y}_{\mathrm{i}}$ dependent variable through their $\hat{\mathrm{Y}}_{\mathrm{i}}$ estimators.

The Fisher test was conducted at a significance threshold of 0,95 . The statistical value of the Fisher test is 44138,1227 , a value which is greatly significant compared to the critical value of the test, which is 9.2666 , thus the null hypothesis of the test being rejected revealing a consistent pattern suitable for the use in the process of forecasting future values. Subsequent to these reviews we concluded that the indicated model is a robust one both economically and econometrically, able to explain the influence of two groups of the identified factors on the formation of GDP.

\section{Conclusions}

In essence, the research on the role of human capital (education circumscribed) in the economic growth have started exactly from the fact that production functions with common factors $(\mathrm{Y}=\mathrm{F}(\mathrm{K}, \mathrm{L}))$ could not explain the advance of growth. The 
results show that a great part of the increase was put down to one or more unidentified factors expressed by a waste of some specification of the productive function. Thus, one factor, which was not perceived as such, was not able to establish a viable growth policy. The concept of human capital allows a theorizing of the well-established empirical relationship between the level of training and salary, the attempts to explain the different growth being placed at the base of the human capital theory genesis. Theoretical studies, but especially empirical ones, as well as obvious facts challenged the traditional assumptions of growth, showing that labor and capital factors were not sufficient on their own to sustain economic growth (GDP growth per capita) and that only a quantitative increase of these two factors could explain part of the accomplished increase.

The financing of the national education system is a key aspect that reflects the effort of the state institutions, either public or private, in achieving superior results, generally the studies indicating the importance of the national characteristics of these expenditures and improvements registered, even if the link between funding and results in education is difficult to be quantified and highlighted. However, the observations and results of the pursued analyses show the importance of expenditure on education to support economic growth, to reduce inequalities and increase productivity etc., representing one of the key choices of governments, companies, and individuals and their families.

The analysis of social capital allows us to consider social development in terms of its accumulation. Clearly put, social capital comprises those features of social relationships - interpersonal trust, norms of reciprocity, participation in civic organizations, and interpersonal and inter-organizational networks - which facilitate cooperation and collective action oriented towards a general benefit, being thus incorporated into the structure and quality of social relationships between people; the notion of social capital refers to a form of capital that is encompassed in the social structure of a group, rather than in physical objects or in single human beings, like physical and human capital. Therefore it can be noted that the institutions' input towards economic success is related to their capacity to support impersonal transactions. The importance of trust to economic performance is reflected by the fact that the lack of it leads to a decreased number of opportunities.

Emphasized is also the social potential induced by social capital, being considered to improve economic activity background in a way similar to technical infrastructure; social capital influences the quality of education and health, facilitates access of individuals to markets, supports complex operations and enables the activities' long-term planning. In this regard it was also stressed the importance of social cohesion towards a country's economic development, the concept of social capital being considered as influencing development theory, practice and policy.

It can be noted that the analysis of social capital at enterprise level would bring about clearer results, as the internal organization of an enterprise is intentionally 
designed to register profit, so this is one of the few cases in which social capital is the product of a specific investment (money spent not only to design internal structures, but also to train managers and workers to work in groups) and not only the by-product of other activities.

We can add that one of the key contributions of social capital is to the accumulation of human capital; it is much easier to develop individual skills in a socially rich environment than in a socially poor one. Since human capital accumulation constitutes an engine of growth in advanced economies, social capital could be regarded as a deep root of growth processes.

The suggested model is important as it reflects a novelty in economic terms, compared to the literature reviewed, based on the fact that it studied separately the influence of the educational component of human capital and the health component of the human capital. Unlike this kind of analysis presented in the literature in the field, the new element brought about by the model proposed in the research studies the simultaneous influence of the factors in these two categories on the formation of the GDP, and the econometric validation of results confirms the theoretical premises which led to the setting-up of this growth model.

The result accomplished, the relationship between the GDP and the independent variables shows that there is theoretical foundation. Greiner and Semmler (2002) indicate that education represents a good for society, being the premise of positive externalities of investments in the economy and education has an important role for society, because it interacts at different levels with different factors, and the results are reflected on the economy. Any economic effort directed towards investment in human capital will stimulate growth through productivity increases.

\section{References:}

Abramovitz, M. 1956. Resource and Output Trends in the United States Since 1870. NBER, http://www.nber.org/book/abra56-1.

Alber, J., Köhler, U., 2004. Health and care in an enlarged Europe. Luxembourg, Office for Official Publications of the European Commission, http://www.eurofound.europa.eu/pubdocs/2003/107/en/1/ef03107en.pdf;

Angelini, E.C, Farina, F. and Pianta, M. 2009. Innovation and Wage Polarisation in Europe. International Review of Applied Economics, 23(3), 309-325.

Babalola, J.B. 2003. Budget Preparation and Expenditure Control in Education. In Basic Text in Educational Panning. Educational Planning.

Bils, M., Klenow, P. 2009. Does Schooling Cause Growth? American Economic Review, 90(5), 1160-1183.

Beine, M., Docquier, F., Rapoport, H. 2009. On the robustness of the brain drain estimates. Centre of Research and Analysis of Migration, Department of Economics, University College of London, Cream Discussion Paper No 17.

Buckingham, M., Clifton, D.O. 2001. Now, discover your strengths. The Gallup Organization, New York. 
Buckingham, M., Coffman, C. 1999. First, Break All The Rules: What The Worlds Greatest Managers Do Differently. The Gallup Organisation, New York.

Cascio, F.W. 1991. Costing Human Resources: The Financial Impact of Behavior in Organizations. Human Resource Management Editions.

Cismaş, L.M., Costea, C. 2012. The relevance of education as a capital asset for economic development: References to the Romanian situation. Procedia, Social and Behavioral Sciences, 3582-3587.

Cismaş, L.M., Mungiu-Pupăzan, M.C. 2012. Dynamic Economic efficency in the South West Oltenia Region. Analele Universităţii Constantin Brâncuşi, Târgu Jiu, Seria Economica.

Cismaş, L.M., Sîrghi, N. 2013. Quality assurance in education by linking the Romanian Academic Sytem to Europe 2020 Objectives. Editura Mirton Publ.

Cismaş, L.M., Oţil, M., Ganciov-Miculescu, A. 2015. Disparities in Regional economic development in Romania. Analele Ştiinţifice ale Universităţii Alexandru Ioan Cuza, Iaşi.

Cohen, D. and Soto, M. 2001. Growth and human capital: Good data, good results. SpringerLink.

Coleman, J. 1990. Foundations of Social Theory. Cambridge, Harvard University Press.

Criveanu, I. and Iordache, L. 2015. Establishing Human Resources Strategies and Policies Correlating with Company's Objectives. International Journal of Economics \& Business Administration, 3(4), 3-10.

Denison, E.F. 1962. The Sources of Economic Growth in the United States and the Alternatives before Us. Committee for Economic Development, New York.

Eurostat, http://eppsso.eurostat.ec.europa.eu/.

Fukuyama, F. 1995. Trust: The Social Virtues and the Creation of Prosperity. NY Free Press, $\mathrm{XV}, 457 \mathrm{p}$.

Fukuyama, F. 2001. Social capital, civil society, and development. Third World Quarterly, 22(1), 7-20.

Greiner, A. and Semmler, W. 2002. Externalities of Investment, Education and Economic Growth. Economoc Modelling, 19(5), 709-724.

Guskova, D.N., Vdovin, M.S., Krakovskaya, N.I., Slushkina, Yu.Yu. 2016. The Quality of Education as a Primary Concern of the Sustainable Development. European Research Studies Journal, 19(3) Part B, 239-257.

Hategan, C.D., Curea-Pitorac, R.I. 2017. Testing the Correlations between Corporate Giving, Performance and Company Value. Sustainability, 9, 1210. 1-20.

Helliwell, J.F., Putnam, R.D. 1999. Education and Social Capital. NBER Working Paper 7121, http://www.nber.org/papers/w7121.

Huselid, M.A. 1995. The impact of Human Resource Managgement practices on turnover, productivity, and corporate financial performance. Academy of Management Journal, 38(3), 635-872.

Kravetz, D.J. 1988. The human resources revolution: Implementing progressive management practices for bottom-line success. San Francisco, CA, US: Jossey-Bass.

La Fuente, A. and Cicoone, A. 2003. Human capital in a global and knowledge-based economy. Working paper No 70, Barcelona Graduate School of Economics, https://econpapers.repec.org/RePEc:bge:wpaper:70

Layte, R., Maître, B., Whelan, Ch.T. 2010. Second European Quality of Life Survey: Living conditions, social exclusion and mental well-being. Luxembourg, Office for Official Publications of the European Commission, http://www.eurofound.europa.eu/pubdocs/2009/88/en/2/EF0988EN.pdf. 
Manta, A., Badircea, R., Pirvu-Gruescu, R. 2017. The Correlation Corporate GovernanceFinancial Performance in the Romanian Banks. Current Issues in Corporate Responsibility; An International Consideration, CSR, Sustenability, Ethics \& Governance. Editors, Idowu, S.O., Sitnikov, C., Simion, D., Bocean, C.G., ISBN 978-3-319-70448-7, Springer.

Nulla, Mh.Yu. and Koumparoulis, N.D. 2013. CEO Compensation System in Large Canadian Financial Institutions. International Journal of Economics \& Business Administration, 1(1), 137-155.

OECD Education Ministerial Meeting, 2010. Investing in Human and Social Capital: New Challenges, http://www.oecd.org/site/0,3407, en_21571361_44559030_1_1_1_1_1,00.html.

Paldam, M., Svendsen, G.T. 2000. An Essay on Social Capital: Looking for the Fire Behind the Smoke. European Journal of Political Economy, 16, 339-366, http://www.sciencedirect.com/science/article/pii/S0176268099000646.

Philippe, A., Howitt, P., Murtin, F. 2010. The Relationship Between Health and Growth: When Lucas Meets Nelson-Phelps. NBER Working Paper.

Putnam, R. 1993. Making democracy work. Civic traditions in modern Italy. Princeton University Press, Princeton, New Jersey.

Stamatakis, D. 2016. Convergence on Alternative Human Capital Proxy Variables: A Cross Country Empirical Investigation. International Journal of Economics \& Business Administration, 4(1), 86-109.

Sultanova, V.A., Chechina, S.O. 2016. Human Capital as a Key Factor of Economic Growth in Crisis. European Research Studies Journal, 19(2), 72-79.

Putnam, R.D. 1993. What makes democracy work? University of Birmingham, National Civic Review, 82(2).

Thalassinos, I.E., Stamatopoulos, V.T. and Arvanitis, E.S. 2011. Gender wage gap: Evidence from the Hellenic maritime sector 1995-2002. European Research Studies Journal, 14(1), 91-101.

UNDP, http://www.undp.org.

World Bank, http://www.worldbank.com.

World Health Organization, http://www.who.org.

www.gea.org.ro.

www.ilo.org. 